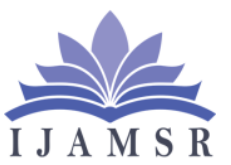

International Journal of Advanced Multidisciplinary Scientific Research (IJAMSR) ISSN:2581-4281

\title{
The Study of Difference in Emotional Intelligence of Under-Graduate Students in Relation to Arts and Science Stream
}

\author{
Manzoor Ahmad Parray \\ Research Scholar, University Institute of Education, Sant Baba Bhag Singh University, \\ Jalandhar, Punjab, India.
}

Email: manzoorparrey12345@gmail.com

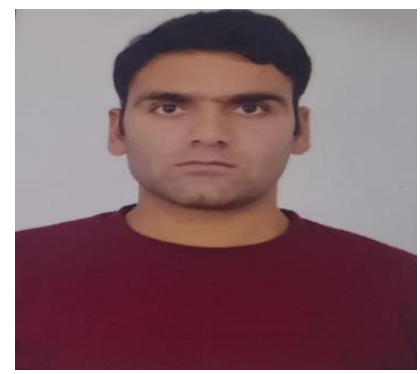

MANZOOR AHMAD PARRAY

\begin{tabular}{l}
\hline Keywords: \\
Undergraduate Students, \\
Emotional Intelligence, Arts And \\
Science Students
\end{tabular}

\begin{abstract}
A B S T R A C T
The purpose of this study was to study the emotional intelligence of under-graduate students of Kashmir division of Jammu and Kashmir. For the study a total sample of 400 individual subjects divided into two divisions of 200 arts and 200 science subjects. The tool used for data collection was Emotional Intelligence Scale (EIS) constructed and standardized by Anukool Hyde, SanjyotPethe and Upinder Dhar (2002). For this study the statistical tools used to be Mean, Standard Deviation and t-test. The findings of the study reveal that there is no significant difference in emotional intelligence of arts and science students.
\end{abstract}

Citation: Manzoor Ahmad Parray (2019). The Study of Difference in Emotional Intelligence of Under-Graduate Students in Relation to Arts and Science Stream. International Journal of Advanced Multidisciplinary Scientific Research (IJAMSR) ISSN:2581-4281, 2 (1), January, 2019, \# Art.1119, pp 59-64
Introduction

Emotional intelligence (El) is generally a new area of research in the Indian setting. The term emotional intelligence itself was utilized in the 1960s out of a coincidental form in artistic feedback (Van Ghhent, 1961) [8] and Psychiatry (Leuner, 1966) [5]. The converging of emotion and insight as a cognitive capacity under the subtitle emotional intelligence was formally proposed by Yale clinician Salovey and Mayer in 1990 [7] in the 'Journal of imagination and personality'. The idea was promoted by Goleman's (1995) [2] top of the line book 'Emotional intelligence' 


\section{International Journal of Advanced Multidisciplinary Scientific Research (IJAMSR) ISSN:2581-4281}

the cover article in the 'Time' (Gibbs, 1995) [1] and after that some other famous books. Salovey and Mayer (1990) [7] at first utilized the expression "Emotional intelligence" in distributed written work and characterized emotional intelligence as: "a type of insight that incorporates the capacity to screen one's own particular and others sentiments and emotions, to segregate among them and to utilize this data to direct one's reasoning and activities".

As indicated by the western view, emotional intelligence is a psychological capacity or expertise to be obtained by a person through various leveled arrangements of these capacities. It is, notwithstanding, recognized for socially important qualities, for example, warmth, trust value, amiability and so on. Emotional intelligence refers to a wide arrangement of individual aptitudes and demeanors, for the most part it is known as delicate abilities or interpersonal abilities, these abilities construct a competency profile among people. As per Perkins, et. al. (2005) [6] such aptitudes or capacities are past the customs zones of particular information. Emotional intelligence is the capacity to secure and apply information from our own particular emotions and the emotions of others, keeping in mind the end goal to be more fruitful and lead an additionally satisfying life. It is the inborn potential to feel, utilize, impart, perceive, recollect, depict, distinguish, gain from, oversee, comprehend and clarify emotions (Heinz, 2000) [4].

The idea of emotional intelligence in Indian setting is advanced with significant social concern, characteristics, customs of religion, and social practices. The ethical qualities like peacefulness, mindful, thoughtfulness, generosity are really the emotional articulations esteemed by the Indians. These ethical qualities give the premise to emotional articulations and reaction. The Indian perspective of emotional learning may thusly be identified with the development of 'self through the procedure of self-recognition and self-checking as per the social-social setting.

Emotional intelligence is the capacity to read one's emotions and perceive their effect while utilizing instincts to direct decisions. As such, it is to know about what one feels and having the capacity to name which emotions is going on at some random time. It also includes controlling one's emotions and driving force and adjusting to the evolving situation. It is the capacity to utilize the familiarity with our emotions to remain adaptable and coordinate the conduct decidedly. It is the capacity to see, comprehend the emotional responses while grasping social organizations. Goleman (1998) [3] contended that each individual is born with a general emotional intelligence and these general El choose their potential for learning emotional abilities. Goleman in 1995 [2] defined emotional intelligence as the ability to know, manage one's own emotions, and recognize them in others and to handle the relationships. The individual who has developed his emotional intelligence is better equipped to handle his own feelings and emotions and the feelings and emotions of others. He is also better equipped at understanding the emotions of others and is also able to discriminate among them. 


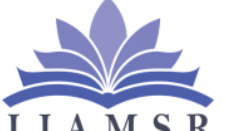

\section{International Journal of} Advanced Multidisciplinary Scientific Research (IJAMSR) ISSN:2581-4281

Emotional intelligence plays a vital role in shaping, directing and modifying the behavior and personality of the individual. Emotional intelligence is the vital element which gives recognition to our own feelings and those of others and to manage them in ourselves and in our relationships. Emotional intelligence promotes selfawareness, self-regulation, self- motivation, empathy and social skills. All those components are very much essential and needed for the satisfaction of the individual.

\section{Objectives}

- To study the level of emotional intelligence of under-graduate students.

- To study the difference in emotional intelligence of arts and science under-graduate students.

\section{Hypothesis}

- There is no significant difference in emotional intelligence of arts and science under-graduate students.

\section{Sample}

The sample for the study was selected from undergraduate colleges affiliated with the Kashmir university of Kashmir region of the state of Jammu and Kashmir by using stratified random sampling. The study consists of 400 students with 200 arts and 200 science students.

\section{Tool Used}

To measure emotional intelligence of student-teachers, Emotional Intelligence Scale (EIS) constructed and standardized by Anukool Hyde, SanjyotPethe and Upinder Dhar (2002) was used. This scale consists 34 items and measures emotional intelligence through 10 factors - self-awareness, empathy, self-motivation, emotional stability, managing relation, integrity, selfdevelopment, value orientation, commitment and altruistic behavior. The reliability of the scale was determined by calculating the reliability coefficient on a sample of 200 students. The split-half reliability coefficient was found to be 0.88 . Besides face validity, as all items were related to the variable under focus, the scale has high content validity.

\section{Statistical Treatment}

Descriptive survey method was used in this study in order to find out the Mean, Standard Deviation, and ttest of the analyzed data.

\section{Statistical Analysis and Interpretation}

By keeping in mind the first objective of this study, the researcher studied the level of emotional intelligence of under-graduate students. On the basis of levels as given in the manual of the scales as low level, average level and high level. After that the investigator used t-test to find significant differences in emotional intelligence of under-graduate students on the basis of arts and science streams. Details pertaining to the analysis are being given separately as follows. 
Levels of Emotional Intelligence of Undergraduate Students

In order to examine the level of emotional intelligence of under-graduate students of Kashmir, the researcher used emotional intelligence scale for collecting information from subjects. The scores of the emotional intelligence scale were calculated and divided into three groups on the basis of values given in the norms of the manual i.e. low emotional intelligence group (LEIG) those who scores less than 131, average emotional intelligence group (AEIG) having scores between 132-144 and high emotional intelligence group (HEIG) having scores higher than 145. The results have been presented in the table 1

Table 1. Level of Emotional Intelligence among Under-Graduate Students

\begin{tabular}{|c|c|c|}
\hline Levels & $\mathrm{N}$ & Percentage \\
\hline HEIG & 90 & $22.5 \%$ \\
\hline AEIG & 192 & $48 \%$ \\
\hline LEIG & 118 & $29.5 \%$ \\
\hline
\end{tabular}

The results of the table 1 revealed that $22.5 \%$ undergraduate students have high emotional intelligence, $48 \%$ have average emotional intelligence and $29.5 \%$ have low emotional intelligence. It means the majority of under-graduate students falls in the average level of emotional intelligence. The result of the above table has been presented graphically through the figure 1

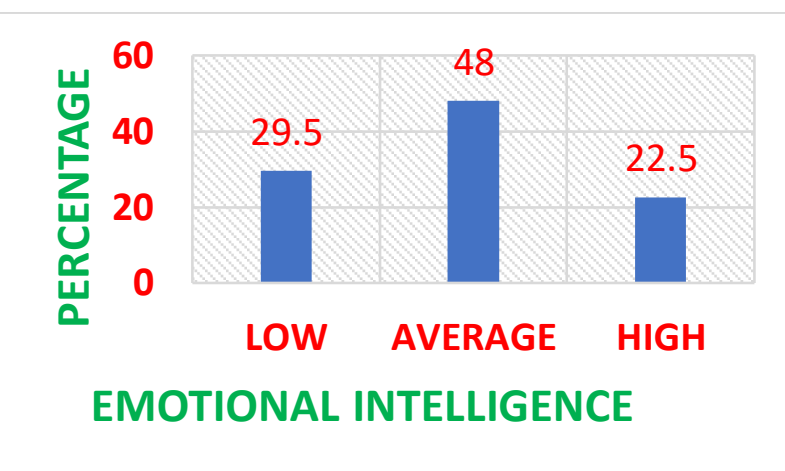

Figure 1 Level of Emotional Intelligence among Undergraduate Students

Difference in Emotional Intelligence of Arts and Science Under-Graduate Students of Kashmir

The second objective of this study was to analyze the difference in emotional intelligence of arts and science under-graduate students of Kashmir. To achieve this objective, the emotional intelligence scores of arts and science undergraduate students of Kashmir were compared using t-test. Means, Standard deviation and Summary of t-test have been presented in the table 2

Table 2. Difference in emotional Intelligence of arts and science under-Graduate Students

\begin{tabular}{|c|l|l|l|l|l|}
\hline $\begin{array}{c}\text { Gro } \\
\text { up }\end{array}$ & N & $\begin{array}{c}\text { Me } \\
\text { an }\end{array}$ & SD & $\begin{array}{c}\text { t- } \\
\text { val } \\
\text { ue }\end{array}$ & Result \\
\hline Arts & $\begin{array}{c}0 \\
0\end{array}$ & $\begin{array}{c}137 \\
.81\end{array}$ & $\begin{array}{c}10 . \\
93\end{array}$ & $\begin{array}{c}0.0 \\
9\end{array}$ & $\begin{array}{c}\text { Insignifi } \\
\text { cant }\end{array}$ \\
\cline { 1 - 3 } Scie & 2 & 137 & 9.9 & & \\
nce & 0 & $\begin{array}{c}131 \\
2\end{array}$ & & & \\
\hline
\end{tabular}

**Insignificant at $0.01 \& 0.05$ level 


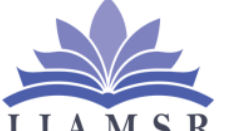

\section{International Journal of} Advanced Multidisciplinary Scientific Research (IJAMSR) ISSN:2581-4281

The table 4.6 showed that the mean difference between arts and science under-graduate students in their emotional intelligence scores. The table reflects that the mean score of arts under -graduate students was 137.81 and science under -graduate students was 137.91 and standard deviation of arts students was 10.93 and science students was 9.92 respectively, $t$ value was found to be 0.09 which was insignificant at both levels of significance. This means that there was an insignificant difference in emotional intelligence of arts and science under-graduate students. Therefore, the first hypothesis of the study, which was stated that "There is no significant difference in emotional intelligence scores of arts and science under-graduate students." Stands accepted, because there was an insignificant difference in the emotional intelligence scores of arts and science under-graduate students. To the best knowledge of the researcher no study has been conducted so far which can support or stand against the findings of the present study. The findings of the present study revealed that there was no significant difference between scores of emotional intelligences of arts and science under-graduate students. The reason for this fact is that we live in the world of information and technology. It has changed the entire scenario of the education system. This information and technology have its impact on all the aspects of the education as well, whether it is curriculum, methods of teaching, the role of the teacher or other aspects of education. All the subjects are taught in an integrated manner. The students whether arts or science is also given the same opportunities and facilities so as to inculcate in them the qualities of emotionality, self- respect, self esteem, patience, self-expression, conflict resolution, understanding for implementing the emotional intelligence in their learning behavior. So, because of these reasons we can say that no difference has remained between scores of emotional intelligences of arts and science under-graduate students.

\section{Conclusion}

On the basis of the various results obtained, some important conclusions have been derived and these are being presented below.

a) $29.5 \%$ under-graduate students have a low level of emotional intelligence, $48 \%$ under-graduate students have an average level of emotional intelligence while as $22.5 \%$ under-graduate students have a high level of Emotional intelligence.

b) Two groups of under-graduate students, i.e. arts and science students do not differ in their Emotional Intelligence. Hence it may be concluded that arts under-graduate students tend not to be significantly higher in emotional intelligence than the urban under-graduate students.

\section{Acknowledgments}

The author appreciates all those who participated in the study and helped to facilitate the research process.

\section{Conflict of Interests}

The author declared no conflict of interests. 
International Journal of Advanced Multidisciplinary Scientific Research (IJAMSR) ISSN:2581-4281 Volume 2, Issue 1, January, 2019

IJAMSR $2(1) \quad$ www.ijamsr.com $\quad$ CrossRef: https://doi.org/10.31426/ijamsr.2019.2.1.1119

International Journal of

I J A M S R Advanced Multidisciplinary Scientific Research (IJAMSR) ISSN:2581-4281

\section{References}

1) Gibbs, N. (1995). EQ factor, Time, 60-68.

2) Goleman, D. (1995). Emotional Intelligence. New York: Bantam Books.

3) Goleman, D. (1998b). Working with Emotional Intelligence. New York: Bantm Books.

4) Heinz, S. (2000). EQ for Everyday. Retrieved from www.http.org/mem.htm

5) Leuner, B. (1966). Emotional intelligence and emancipation. Praxis der Kinder-psycholologie und Kinderpsychiatrie, 15, 193-203. In Mayer, J. D., Salovey, P. \& Caruso, D. R. (2004). Emotional intelligence: theory, findings, and implications. Psychological Inquiry, 3,197215.

6) Perkins, D., Altman, I, \&Gauvain, M. (2005). A crosscultural study of adjustment of international students. Patterson, A. \& Newcombe, N. (Eds.) Spatial representation and behavior across the life span, New York: Academic Press.

7) Salovey, P. \& Mayer, J.D. (1990). Emotional Intelligence. Imagination, cognition and personality (9), 185-211.

8) Van Ghent, D. (1961). The English Novel: Form and Function. New York, Harper and Row. 